\title{
A Critical Review on the Development and Utilization of Energy Systems in Uganda
}

\author{
Ocident Bongomin* and Patrick Nziu \\ ${ }^{1}$ Department of Manufacturing, Textile and Industrial Engineering, School of Engineering, Moi University, \\ P.O. Box 3900-30100, Eldoret, Kenya \\ * Correspondence to be addressed to Ocident Bongomin; ocidentbongomin@gmail.com, ocident@mu.ac.ke
}

\begin{abstract}
We live in the world that is completely entangled on energy and thus, Humankind can no longer do without it, power. With electricity being the main form of energy today, this has increased the complexity of our life today. In Uganda, electricity generation is mainly through hydropower which put the country in the bottleneck of over dependence on one source of energy. Yet, there are many energy systems out there that country can diversify its electricity generation. Therefore, the need to understand, the level of development and utilization of various energy systems has been the underlying question for this present study. Comprehensive literature survey was conducted from the electronic databases including ScienceDirect, Wiley, Sage, Scopus, Taylor \& Francis, and Google Scholar. The publications in form of reports, conference papers, working papers, discussion papers, journal articles, book sections and textbooks were considered in this study. In total, 11 energy systems including human and animal energy, solid biomass (firewood), hydropower, wind, geothermal, solar, nuclear, peat, coal, petroleum, and non-solid biomass (methanol, hydrogen, ethanol, biodiesel, and biogas) are described. The current and the future development and utilization of these energy systems has been described. The challenges with their development and utilization were elaborated and the solution the challenges were presented. The hydropower with River Nile being the main river for large hydropower plant construction is the dominance energy system in Uganda. Nuclear energy will be the salvation for the country's electric energy supply in the near future. Therefore, Uganda needs to bet big on nuclear energy.
\end{abstract}

Keywords: Hydropower, Wind, Solar, Geothermal, Firewood, Nuclear, Petroleum, Peat, Non-solid biomass, Solid biomass, Energy systems, Human energy, Animal energy

\section{Introduction}

Availability of dependable energy performs an essential position withinside the social, economic, and cultural transformation of society. In the case of Uganda, the energy area has suffered long-status facet constraints that led to suppressed call for and outages [1]. Long-term energy demand forecasting is crucial for any country, in particular for developing countries with rapid developments of energy needs [2]. In this line, Uganda continues to politically and economically reformed its energy sector including a new legal and regulatory framework based on which the previously vertically integrated monopoly, Uganda Electricity Board, was unbundled leading to public private partnerships. The Government provides an enabling environment for private sector investments in generation and distribution of electricity while transmission above $33 \mathrm{kV}$ remains a public function through the Uganda Electricity Transmission Company Ltd (UETCL). The Electricity Regulatory Authority (ERA) was established to oversee the operations of all electricity operators, and the Rural Electrification Agency (REA) was launched to ensure that rural electrification, which in most cases is not commercially viable, is accelerated to achieve set targets [3]. In a battle of increasing access to clean energy, and as well, accelerate electricity access to the unserved rural population in Uganda, the government has officially licensed nine Electricity Distribution Companies including, Kilembe Investments Limited, Hydromax, Pader-Abim Community Multi-Purpose Electric Cooperative Society, Uganda Electricity Distribution Company, Umeme Uganda Limited, West Nile 
Rural Electrification Company, Kyegegwa Rural Energy Cooperative Society, Bundibugyo Electricity Cooperative Society, and Kalangala Infrastructure Services Limited [4].

Currently, Uganda has a total of 24 powerplants that generate and supply electricity to the national grid. These includes 4 large hydropower plants and 11 small hydropower plants (1023.59 MW), 2 thermal or Heavy Fuel Oil power plants (100MW), 5 bagasse-based cogeneration power plants $(63.9 \mathrm{MW})$, and 2 Solar PV power plants (60MW). To this end, there is no wind power share to the total national installed capacity. The distribution of electricity in Uganda has expanded enormously in over two decades, with legally grid-connected customers rising from 180,000 in 2001 to $1,643,288$ in 2020 , including Off-Grid clients. However, the country has the electricity import capacity of 20.5 MW from two power plant in the neighboring countries [5].

To this far, Uganda owns abundant energy resources which are fairly distributed throughout the country [6]. These include hydro, biomass, solar, geothermal, peat and fossil fuels with the petroleum in an estimated amount of 6.5 billion barrels, of which 1.4 billion barrels are recoverable, has been discovered in the western part of the country. However, currently the country's electricity generation is mainly through hydropower. This alone is not sufficient to supply the whole population in the country making electricity prices expensive besides other factors such as oil price fluctuation and the exchange rate [7]. Electricity in Uganda is not the most expensive but also not the cheapest compared to other Sub-Saharan African countries [8, 9]. As per 2018, Uganda's electricity price was below Rwanda's and Kenya's tariff, but above the tariff of Tanzania, South Africa and Ethiopia [10]. Ang et. al [11] reported that highly volatile oil prices and unprecedented weather fluctuations have acted as significant shocks for electricity generation, influencing electricity pricing. Moreover petroleum resources brings its own problem as it is very difficult for the developing country like Uganda to balance their economic development needs and contribution to combating climate change [12]. The rising electricity price in the country brings great challenge to the consumers, especially the large industrial consumers. However, Ai et al [13] urged that increasing electricity price has good side in that it could force the enterprises to carry out technological innovation, and improve efficiency of energy utilization.

The government intervention is paramount importance to reducing the electricity and petroleum prices. Especially in the rural area through the rural electrification program, the price of electricity is reduced and the suppliers are compensated. This is done through subsidy policy [14]. Moreover, incorporating the heterogeneous nature of price elasticities into pricing policy can help decrease electricity demand-supply mismatch and inequality in electricity consumption [15]. In most developing countries electricity pricing is determine the mechanism called Automatic Tariff Adjustment [16, 17]. On the other hand, petroleum prices are very flexible since Uganda does not refine their oil though there's large amount of crude oil deposit. It has to export the export oil and import the refined ones, and thus the price structure will depend on the many factors including transportation, pandemic, and inflation [18-20]. For instance, the COVID-19 pandemic led to the oil price shock which hit oil-exporting developing countries as well as the importing countries [21]. Raghoo \& Surroop [22] cited that transportation and taxation policies are the major parameters for determining petroleum prices.

With electricity being the main form of energy today, it has increased the complexity of life today. In Uganda, electricity generation is mainly through hydropower which put the country in the bottleneck of over dependence on one source of energy. Yet, there are many energy systems out there that country can diversify its electricity generation. Therefore, the need to understand the level of development and utilization of various energy systems has been the underlying question for this present study. The contributions of this paper are trifold: (i) describe the current status, (ii) discuss the challenges and mitigation, and (ii) provide the future trends of energy systems development and utilization in Uganda. The present paper is structured as followed, section 2 following the introduction section presents the review of the different energy systems. Section 3 provides the brief discussion on each energy system, and lastly the conclusion section. 


\section{Review}

\subsection{Human and animals Energy}

\subsubsection{Current status of utilization}

In Uganda, human and animal power still contribute a significant proportion of the energy used in the rural areas. They are the most important energy sources for their populations which is the largest single contributor of the renewable energy sources [23]. Figure 1 clearly demonstrates the concept of harnessing animal power as an input-output block diagram.

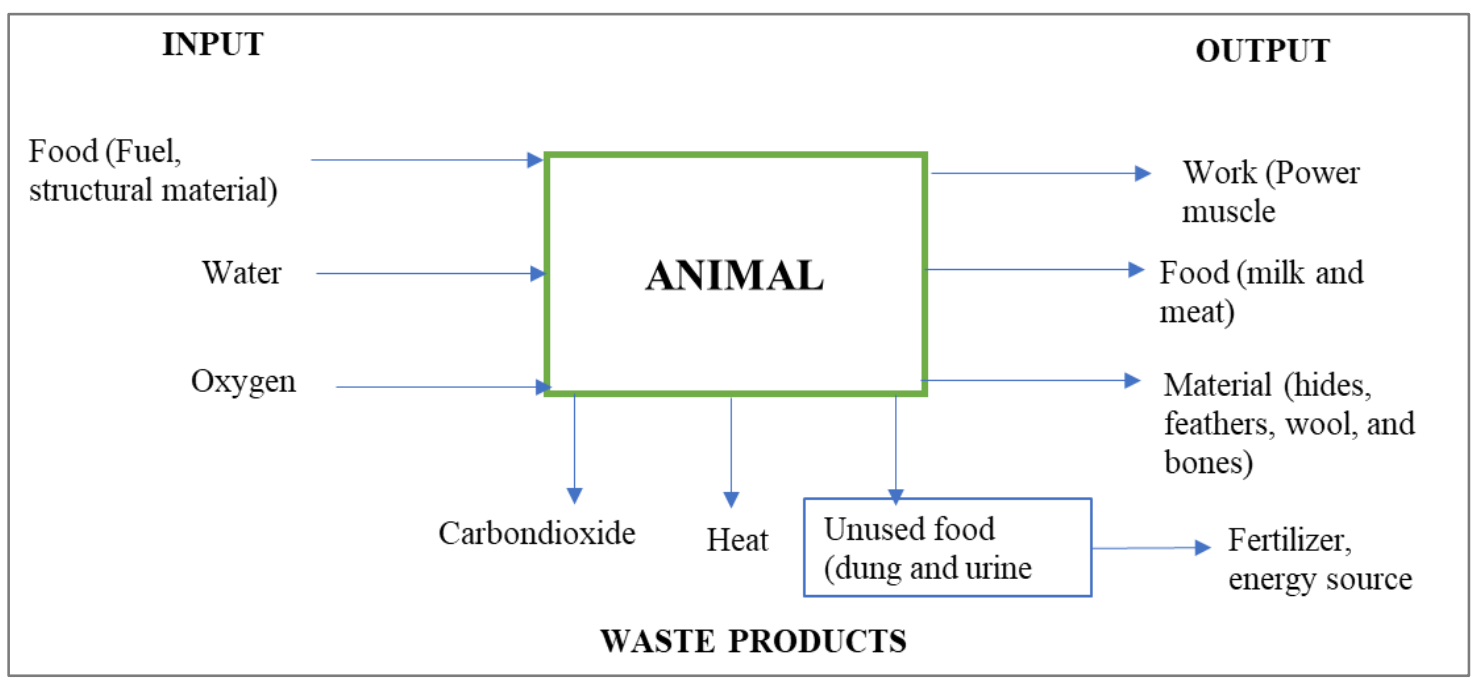

Figure 1. Input-Output block for working animals, adapted from Fuller and Aye [23]

The human and other animals' energy are largely employed in agriculture, crop processing, transportation, construction and fabrication work, industrial manufacturing process (operating machines). Agriculture still dominates the proportion of human and animal power followed by transportation (Table 1) [24]. Whereby human and animal power is the elementary level of mechanizing agricultural and forestry operations. These agricultural operations include but not limited to the following: clearing of vegetation/stubble including cutting trees (machetes, axes, hand and chain saws), land preparation and soil manipulation (blade and tined hoes and pickaxes), seeding or planting (broadcasting by hand or seed fiddle, dibbling, jab planting and use of single or multirow seeders), weeding (weeding hoes and cultivator weeders), fertilizer and manure application, crop protection (manual or power knapsack sprayers and dusters), harvesting (scythes, sickles, knives, drags, forks and rakes), processing and preservation of food and feed (baling, mechanical threshing, manual and mechanical shelling and grinding), transportation (head or shoulder load, backpack, handcarts and bicycles), and other secondary tasks such as operation of hand and treadle pumps to lift water.

Table 1. Comparison of load carrying capacity and distances for hand-and foot-operated devices.

\begin{tabular}{lcccc}
\hline Transport mode & $\begin{array}{l}\text { Typical load } \\
(\mathrm{kg})\end{array}$ & $\begin{array}{l}\text { Average speed } \\
(\mathrm{Km} / \mathrm{h})\end{array}$ & $\begin{array}{c}\text { Daily range } \\
(\mathrm{km})\end{array}$ & $\begin{array}{c}\text { Transport } \\
\text { capacity }(\mathrm{t} \mathrm{km} / \mathrm{h})\end{array}$ \\
\hline Human carrying & 30 & $4-5$ & $15-20$ & 0.12 \\
Wheelbarrow & 90 & $3-4$ & $5-6$ & 0.35 \\
Handcart (1 person) & 200 & $3-4$ & $10-12$ & 0.80 \\
Cycle with carrier & 40 & 12 & $40-50$ & 0.48 \\
Cycle trailer & 125 & 10 & $30-40$ & 1.25 \\
Donkey cart (1 animal) & 300 & $3-4$ & 20 & 1.10 \\
Ox Cart (2 animals) & 900 & $3-4$ & 20 & 3.20 \\
\hline
\end{tabular}

Source: adapted from [25] 


\subsubsection{Challenges being experienced and their possible mitigation}

Despites of the fact that human and animal power is the most common energy used by the people in Uganda, they have some drawbacks. The cost of the improved technologies is a significant barrier to human and animal power adoption. For instance, many people in the villages are carrying loads on the head or back, means that rural people are unable to afford simple technologies such as wheelbarrows, handcarts, bicycles and animal-drawn carts. Secondly, there is high isolation of those who would benefit most from the introduction of more efficient hand and animal-powered technologies is also a major factor influencing the steps in a successful technology transfer process [24].

The following can be possible mitigation for human and animal power drawbacks [26]: (i) proper tools to harness the power from human and animals, (ii) appropriate and sufficient feed to ensure health and growth, as well as energy for work, (iii) adequate health care and prompt provision of veterinary services in case of injuries and sickness, and to aid resistance to disease, (iv) appropriate well-fitting equipment for working, prevention of injury while working, etc., (v) prevention of overstraining, allowing human and animals to rest from work while sick or injured, and avoiding putting animals to work in adverse ambient conditions, (vi) ensuring observance of laws to prevent the misuse and abuse of draught animals, (vii) use of modern equipment and methods for surgical treatments and slaughter, (viii) Allowing animals, the freedom to satisfy natural instincts $\mathrm{h}$. Adoption of human methods for nose-roping, shoeing, branding, dehorning, etc., and (ix) development of publicity and education programmes by animal welfare organisations.

\subsubsection{Future trends}

There is a dire need to increase the energy supply of those who rely on traditional energy sources in order to improve their quality of life and reduce the drudgery and hardship of everyday life. Human and animal energy is the forgotten renewable sources of energy that is environmentally friendly and sustainable energy supply system. However, the technologies used to harness this system are simple and reliable but needs much attention [27].

\subsection{Solid Biomass Energy}

\subsubsection{Current status of utilization}

In Uganda, the use of low-grade forms of energy (especially traditional or solid biomass fuels), account for more than $90 \%$ of total energy consumption. With the large number of refugee in the country, energy supply is so limited especially for energy for cooking (firwood) [6]. The use of nonprocessed biomass sources of energy or solid biomass (i.e., crop residue and wood fuel) illustrates energy poverty among households [28]. In addition, wood fuel is used extensively for process heat and to fuel brick-burning, tea drying, cement, titles and lime production. The major sources are hardwood plantations, which consist of eucalyptus $(50 \%)$, pine trees $(33 \%)$ and cypresses $(17 \%)$. The current available sustainable wood biomass supply is about 26 million tons. The annual theoretical potential production of agriculture residue ranges from 1.186 million to 1.203 million tons. The only sub-sector that utilizes biomass residues for electricity production yet is the sugar industry [29, 30].

\subsubsection{Challenges being experienced and their possible mitigation}

Firewood or wood fuel is the main source of heating and cooking in rural and urban areas. The high demand for fuel wood has resulted in the depletion of forests, and exacerbates land degradation. This type of energy source is associated with higher levels of indoor pollution, time allocations especially by women and children for its collection, unreliability of supply and local environment degradation. The use of firewood is therefore a detrimental factor in welfare improvement and constraint to the achievement of all the eight Millennium Development Goals [31].

The above challenges can be mitigated by use of alternative energy source or processed wood fuel such as charcoal, briquettes, and other agricultural residues are very important to reduce over reliance on firewood [32]. The charcoal is typically produced in low-efficiency earth kilns in rural 
areas and high losses are experienced through- out the value-chain. LPG, natural gas and electricity are used mostly by the high-income groups, normally in the urban areas [33]. However, massive use of these energy sources can end the energy poverty in the country [34]. With these regards, it can be noted that energy use varies considerably depending on income and geographical location of the household.

\subsubsection{Future trends}

The efficiency of the traditional and institutional cook stoves is being improved to reduce the consumption of firewood. Moreover, the efficiency rates in term of energy consumption industries such as tea, tobacco, lime, and brick-making are being improved. Importantly, the key tool for this is the energy audits to identify potential measures to improve energy efficiency.

\subsection{Hydropower Energy}

\subsubsection{Current status of utilization}

There are three kinds of hydropower generation plants: (i) run-of-river, where the power is generated by the flow of a river, (ii) reservoir, where the power is generated by the release of stored water, and (iii) pumped storage, where stored water is backed up into the reservoir in order to be pumped again [35][36]. Small scale hydropower stations are typically of the run-of-river type while the large hydropower plants are reservoir type [37]. The large hydropower potential in Uganda along River Nile is estimated at about 2000MW. With only 380MW developed at Nalubaale and Kiira, and 250MW under development at Bujagali, the unexploited potential is well over 1300MW. Table 2 shows the seven (7) operational large hydropower plants along River Nile, River Mahoma, and River Achwa with the total capacity of $926 \mathrm{MW}$ [38].

Table 2. Operational Large Hydropower plants in Uganda

\begin{tabular}{ccclcc}
\hline S/N & Power stations & $\begin{array}{l}\text { Community } \\
\text { (district) }\end{array}$ & River & $\begin{array}{l}\text { Capacity } \\
\text { (MW) }\end{array}$ & $\begin{array}{l}\text { Year } \\
\text { completed }\end{array}$ \\
\hline 1. & Nalubaale & Buikwe & Nile & 180 & 1954 \\
2. & Kiira & Jinja & Nile & 200 & 2000 \\
3. & Bujagali & Buikwe & Nile & 250 & 2012 \\
4. & Mahoma & Kabarole & Mahoma & 30 & 2018 \\
5. & Isimba & Kamuli & Nile & 183 & 2019 \\
6. & Achwa 2 & Gulu & Achwa & 41 & 2019 \\
7. & Achwa 1 & Gulu & Achwa & 42 & 2021 \\
& TOTAL & & & 926 & \\
\hline
\end{tabular}

Source: adapted from Tumwesigye et al. [9]

Small hydropower $(<20 \mathrm{MW})$ projects are mainly not on the Nile River, and have not been fully exploited. These are important sources of electricity for areas not covered by the national grid. Even though the cost per unit of electricity from isolated small hydropower plants may be higher than that from the national grid, they could sustainably contribute to poverty reduction in households in isolated areas. Table 3 shows the small hydropower sites available for development in Uganda. There are currently 25 small hydropower plants which are operational with the total capacity of $195.5 \mathrm{MW}$.

Table 3. Operational small hydropower plants (<20 MW) (including micro and pico)

\begin{tabular}{llllll}
\hline S/N & Power stations & $\begin{array}{l}\text { Community } \\
\text { (district) }\end{array}$ & River & $\begin{array}{l}\text { Capacity } \\
(\mathrm{MW})\end{array}$ & $\begin{array}{l}\text { Year } \\
\text { completed }\end{array}$ \\
\hline 1. & Mubuku 1 & Kasese & Mubuku & 5.0 & 1956 \\
2. & Mubuku 3 & Kasese & Mubuku & 10.0 & 2009 \\
3. & Bugoye & Kasese & Mubuku & 13.0 & 2009 \\
4. & Kisiizi & Rukungiri & Kisiizi & 0.4 & 2009 \\
\hline
\end{tabular}




\begin{tabular}{llllll}
\hline S/N & Power stations & $\begin{array}{l}\text { Community } \\
\text { (district) }\end{array}$ & River & $\begin{array}{l}\text { Capacity } \\
\text { (MW) }\end{array}$ & $\begin{array}{l}\text { Year } \\
\text { completed }\end{array}$ \\
\hline 5. & Echo Power- Ishasha & Kanungu & Ishasha & 6.6 & 2011 \\
6. & Afric EMS-Mpanga & Kamwenge & Mpanga & 18.0 & 2011 \\
7. & Nyagak 1 & Zombo & Nyangak & 3.5 & 2012 \\
8. & Kabalega & Hoima & Wambabya & 9.0 & 2013 \\
9. & Bwindi Community & Kanungu & Munyaga & 0.1 & 2014 \\
10. & Siti 1 & Bukwo & Siti & 6.1 & 2017 \\
11. & Muvumbe & Kabale & Maziba & 6.5 & 2017 \\
12. & Rwimi & Bunyangabu & Rwimi & 5.6 & 2017 \\
13. & Siti 2 & Bukwo & Siti & 16.5 & 2017 \\
14. & Gwera-Luzira & Moyo & Amoa & 6.1 & 2017 \\
15. & Nyamwamba 1 & Kasese & Nyamwamba & 9.2 & 2018 \\
16. & Nkusi & Kasese & Nkusi & 9.6 & 2018 \\
17. & Lubilia & Hoima & Lubilia & 5.4 & 2018 \\
18. & Nyamangasani II & Kasese & Nymasagani & 6.0 & 2019 \\
19. & Kyambura & Rubirizi & Kyambura & 7.6 & 2019 \\
20. & Ndugutu & Bundibugyo & Ndugutu & 5.9 & 2019 \\
21. & Sindila (Butama) & Bundibugyo & Sindila & 5.3 & 2019 \\
22. & Timex Bukinda & Kibale/Hoima & Nkusi & 6.5 & 2020 \\
23. & Kikagati & Isingiro & Kagera & 14.0 & 2021 \\
24. & Kakaka & Kasese & Rwimi & 4.6 & 2021 \\
25. & Nyamagasani I & Kasese & Nyamagasani & 15.0 & 2021 \\
& TOTAL & & & 195.5 & \\
\hline
\end{tabular}

Source: Adapted from Tumwesigye et al. [9] and ERA [39]

\subsubsection{Challenges being experienced and their possible mitigation}

In this section, the challenges and mitigations for hydropower development in Uganda have been described. Hydropower projects require huge investment costs because of civil engineering work cost, equipment cost, land compensations costs and transmission system cost. To minimize these, the engineering hydropower policy in Uganda should consider large dam projects with a smaller reserve surface area in comparison with power generated [40, 41].

Further, there are low human and institutional capacities to manage design, construction and management of hydropower plants are another barrier to hydropower plant development in Uganda. This can be reduced by developing local capacity in order to minimize dependency on costly foreign expatriates, conditions should be set in the agreements with hydropower developers to train local manpower to manage the hydropower plants, and clear deadlines established to when the local manpower should take over from the foreign expatriates. Furthermore, specialized curriculums in collaboration with industrial partners should be developed by Uganda's Universities in energy technologies with focus on hydropower and other energy resources in the country [42].

In addition, there is high resistance to hydropower projects from the community because hydropower development process is considered a threat to livelihoods, ecosystem and biodiversity as it brings about human displacement and natural resources degradation. To solve the problem, the government of Uganda needs to establish a clear and well-defined resettlement plan for natives that are to be displaced by the establishment of hydropower generation plants. The resettlement plan should be discussed by the affected populace and the project development partners to come up with a win-win resolution $[43,44]$.

Lastly, hydropower generation depends on the run-of river water, which has a direct relationship with the amount of water entering and leaving the rivers. Climate change has a major impact on the electricity infrastructure in the country due weather extremes like floods that damage hydropower spillways and damage the electricity transmission infrastructure. Ugandan rivers are being tapped as a resource for the generation of hydropower in addition to other uses such as 
irrigation and fishing. To minimize the effects of climate change and variation, the government may consider massive investment in small and medium scale hydropower instead of large-scale hydropower generating plants. This is because the small hydropower plants depend on less water levels to run turbines, and hence are less affected by reduced water levels. Therefore, it very important to forecast the water level using software and other tools [45, 46].

\subsubsection{Future trends}

In order for the country to meet its the energy demand, many hydropower plants are under construction and some are being proposed. So far so good, five (5) large hydropower plants are under construction, while three (3) have been proposed with the combined capacity of $2514 \mathrm{MW}$ as shown in Table 4. Five small hydropower plants (32 MW) are under construction and twenty-seven (125.6 MW) have been proposed as presented in Table 5 and Table 6 , respectively. While thirteen (5.66 MW) are under preliminary studies and some of them have no studies as depicted in Table 7.

Table 4. Proposed and under construction large hydropower plant

\begin{tabular}{llllll}
\hline S/N & Power stations & Community (district) & River & $\begin{array}{l}\text { Capacity } \\
\text { (MW) }\end{array}$ & $\begin{array}{l}\text { Year to be } \\
\text { completed }\end{array}$ \\
\hline 1. & Achwa 3 & Pader & Achwa & 135 & 2022 \\
2. & Karuma & Kiryandongo & Nile & 600 & 2023 \\
3. & Ayago & Nwoya & Nile & 880 & 2025 \\
4. & Agbinika & Yumbe & Tochi & 20 & 2025 \\
5. & Nshungyezi & Isingiro & Kagera & 39.0 & 2025 \\
6. & Kiiba & Kiryandongo and Nwoya & Nile & 400 & WIP \\
7. & Oriang & Kiryandongo and Nwoya & Nile & 392 & WIP \\
8. & Muzizi & Kibaale & Muzizi & 48 & WIP \\
& TOTAL & & 2514 & \\
\hline
\end{tabular}

Source: Adapted from ERA [47] and Get FiT Uganda [48]

Table 5. Small hydropower plants ( $<20 \mathrm{MW}$ ) (including micro and pico) under construction

\begin{tabular}{llllll}
\hline S/N & Power stations & Districts & River & $\begin{array}{l}\text { Capacity } \\
(\mathrm{MW})\end{array}$ & $\begin{array}{l}\text { Year to be } \\
\text { completed }\end{array}$ \\
\hline 1. & Nengo Bridge & Rukungiri & Mirera & 6.7 & 2022 \\
2. & Nyagak 3 & Zombo & Nyagak & 5.6 & 2022 \\
3. & Nyamwabwa 2 & Kasese & Nyamwabwa & 7.8 & 2022 \\
4. & Muyembe & Kapchorwa & & 6.9 & 2022 \\
5. & Nyagak 2 & Zombo & Nyagak & 5.0 & 2023 \\
& TOTAL & & & 32.0 & \\
\hline
\end{tabular}

Source: adapted from ERA [47]

Table 6. Proposed small hydropower plants ( $<20 \mathrm{MW}$ ) (including micro and pico hydropower plants)

\begin{tabular}{|c|c|c|c|c|c|c|}
\hline $\mathrm{S} / \mathrm{N}$ & Power stations & $\begin{array}{l}\text { Community/ } \\
\text { district }\end{array}$ & & River & $\begin{array}{l}\text { Capacity } \\
\text { (MW) }\end{array}$ & $\begin{array}{l}\text { Year to be } \\
\text { completed }\end{array}$ \\
\hline 1. & Nsongi & Bunyangabu & & Nsongya & 7.0 & WIP \\
\hline 2. & Kiraboha & Kasese & & Rwimi & 5.0 & WIP \\
\hline 3. & Latoro & Nwoya & & Achwa & 4.2 & WIP \\
\hline 4. & Buwangani & Manafwa & & Manafwa & 7.0 & WIP \\
\hline 5. & Nyakinengo & Kanungu & & Nchwera & 5.2 & WIP \\
\hline 6. & Lower Achwa & $\begin{array}{l}\text { Lamwo } \\
\text { Amuru }\end{array}$ & and & Achwa & 17.4 & WIP \\
\hline 7. & Awera & Pader & & Achwa & 18.0 & WIP \\
\hline 8. & Okollo & Arua & & Ora & 5.0 & WIP \\
\hline
\end{tabular}




\begin{tabular}{|c|c|c|c|c|c|}
\hline $\mathrm{S} / \mathrm{N}$ & Power stations & $\begin{array}{l}\text { Community/ } \\
\text { district }\end{array}$ & River & $\begin{array}{l}\text { Capacity } \\
(\mathrm{MW})\end{array}$ & $\begin{array}{l}\text { Year to be } \\
\text { completed }\end{array}$ \\
\hline 9. & Rwembya & Kasese & Rwembya & 0.4 & WIP \\
\hline 10. & Lwakhakha & Namisidwa & Lwakhakha & 6.7 & WIP \\
\hline 11. & Senok Atari 1 & Kapchorwa & Atari & 3.3 & WIP \\
\hline 12. & Kabeywa 1 & Bulambuli & Mbigi & 6.5 & WIP \\
\hline 13. & Kabeywa 2 & Kapchorwa & Sirimityo & 2.0 & WIP \\
\hline 14. & Sironko & Sironko & Sironko & 7.0 & WIP \\
\hline 15. & $\begin{array}{l}\text { Nyabuhuka- } \\
\text { Mujunju }\end{array}$ & Bunyangabu & Nsongya & 3.2 & WIP \\
\hline 16. & Simu & Bulambuli & Simu & 9.5 & WIP \\
\hline 17. & Sisi & Bulambuli & Sisi & 7.0 & WIP \\
\hline 18. & Kigwabya & Kagadi & Nkusi & 4.2 & WIP \\
\hline 19. & Warugo & Bushenyi & Warugo & 0.5 & WIP \\
\hline 20. & Igassa & Bunyangabu & Igassa & 0.3 & WIP \\
\hline 21. & Tokwe & Bundibugyo & Tokwe & 0.3 & WIP \\
\hline 22. & Nyahuka & Bunyibugyo & Nyahuka & 0.7 & WIP \\
\hline 23. & Nsongya & Bunyangabu & Nsogya & 0.7 & WIP \\
\hline 24. & Katooke & Kasese & Nyabyayi & 0.3 & WIP \\
\hline 25. & Nchwera & Mitooma & Nchwera & 0.5 & WIP \\
\hline 26. & Hoima & Hoima & Hoimo & 3.3 & WIP \\
\hline \multirow[t]{2}{*}{27.} & Kabasanja & Kabarole & Wamikia & 0.4 & WIP \\
\hline & TOTAL & & & 125.6 & \\
\hline
\end{tabular}

WIP- work in progress, Source: adapted from ERA [47]

Table 7. Small hydropower plant (micro and pico) available for development

\begin{tabular}{|c|c|c|c|c|}
\hline $\mathrm{S} / \mathrm{N}$ & Power stations & District & $\begin{array}{l}\text { Estimated } \\
\text { Capacity } \\
(\mathrm{MW})\end{array}$ & Status \\
\hline 1 & Ela & Arua & 1.5 & No studies \\
\hline 2 & Ririma & Kapchorwa & 1.5 & No studies \\
\hline 3 & Rwigo & Bundibugyo & 0.48 & No studies \\
\hline 4 & Nyarwodo & Nebbi & 0.4 & No studies \\
\hline 5 & Agoi & Arua & 0.35 & No studies \\
\hline 6 & Kitumba & Kabale & 0.2 & No studies \\
\hline 7 & Tokwe & Bundibugyo & 0.4 & $\begin{array}{l}\text { Preliminary technical studies carried } \\
\text { out under AERDP by MEMD }\end{array}$ \\
\hline 8 & Amua & Moyo & 0.18 & No studies \\
\hline 9 & Ngiti & Bundibugyo & 0.15 & $\begin{array}{l}\text { Preliminary technical studies carried } \\
\text { out under AERDP by MEMD }\end{array}$ \\
\hline 10 & Leya & Мoyo & 0.15 & No studies \\
\hline 11 & Nyakibale & $\begin{array}{l}\text { Rum } \\
\text { Rukungiri }\end{array}$ & 0.1 & No studies \\
\hline 12 & Miria Adua & Arua & 0.1 & No studies \\
\hline 13 & Manafwa & Mbale & 0.15 & $\begin{array}{l}\text { Preliminary technical studies carried } \\
\text { out under AERDP by MEMD }\end{array}$ \\
\hline & TOTAL & & 5.66 & \\
\hline
\end{tabular}

Source: adapted from ERA [47] 


\subsection{Wind Energy}

\subsubsection{Current status of utilization}

Wind energy is not yet developed, and presently it is unused resource in the country for electricity generation. However, the wind speeds thought to be commercially viable are found in Tororo, Pader and Nakapiripirit districts. The average wind speeds in these region ranges from 7-9 $\mathrm{m} / \mathrm{s}$ at a height of $80 \mathrm{~m}$. Nevertheless, the wind speed in most areas of Uganda is moderate, with average wind speeds in low heights $(>10 \mathrm{~m}$ ) between $2 \mathrm{~m} / \mathrm{s}$ to $4 \mathrm{~m} / \mathrm{s}$. Therefore, the wind energy resource in Uganda is only sufficient for small scale electricity generation and for special applications, such as water pumping mainly in the Karamoja region [47]. The other current use of wind energy has been identified to be used for small scale irrigation [49].

\subsubsection{Challenges being experienced and their possible mitigation}

The following are the challenges hindering the wind energy development in Uganda and their mitigation approaches.

There are currently insufficient wind resource data within the country which is demanded by the wind energy projects. These data should be consistent and reliable data from different locations within the country. In order to overcome this, there is need to develop wind energy data center to collect and analyze wind data parameters across the country [50,51]. Secondly, there are challenges regarding wind variability and intermittency, this is a common natural occurrence in any geographical location across the world. This challenge affects power generated, may cause turbine faults, and can com- pound inaccuracies in load forecasting.

Development of wind power farms requires a skilled workforce for wind resource assessment, infrastructure installation, operation, and maintenance especially in the implementation of large wind projects which is currently lacking in the country. This can be minimized through capacity building which can be achieved by deliberately advancing long term capacity and technical knowhow in wind power technologies through training, research and development [50].

The technologies used for wind power generation and supply are very expensive. An initial cost of investing in wind power is approximately $80 \%$ of the total project costs. Additional costs are operation, maintenance, and insurance. The high investment cost can be minimized by financial risk transfer approach. This constitutes of instruments that transfer a proportion of the risk to public sector agencies, and include Feed-in Tariffs (FiTs), subsidies, Feed-in Premiums (FiPs), auctions, green bonds, equity financing, and or hard loans [51].

The volatility of wind energy interferes with the system's capability to control electricity supply. The control of wind energy intermittency due to climate change is even more complex with weak grid infrastructure, due to inexistent or sufficient high-power voltage transmission. Wind energy generation is categorized as non-synchronous and is associated with instability effects on an electricity system due to low inertia levels. This weak infrastructure can be reduced by expanding grid infrastructure that could ease connectivity to the grid by independent wind energy producers, attract private investors, and broadly, increase efficiency in the generation and distribution of electricity [52].

\subsubsection{Future trends}

In Uganda, wind energy is still being harnessed in traditional manner such as windmill, winnowing, and many other. There is effort to developed and installed wind turbines in some of the selected sites across the country. This is aimed at achieving renewable energy to back-up the hydropower energy which is currently the dominant clean energy in the country. 


\subsection{Solar Energy}

\subsubsection{Current status of utilization}

In the current situation, only $28 \%$ of the population have access to electricity which not reliable in the country. However, Uganda presents a huge market potential for alternative technologies to provide electricity such as solar energy, photovoltaic ( PV) systems [53]. Solar energy is underutilized in the country although this is slowly changing. Overall, the projected solar penetration in different part of the country by the year 2021 was $6.1 \%$ with the total annual energy was estimated at $69.52 \mathrm{GWh}$ [54]. The use of solar PV started in the 1980s and has been utilized for lighting, vaccine refrigeration in health centres, communications, and signaling for the railways and for telecommunication. In 2014, two $10 \mathrm{MW}$ solar power stations (Tororo Solar Power Station and Soroti Solar Power Station) in the east of Uganda were licensed by the ERA [55]. There exist several PV solar panels with different market segments including Pico and micro solar home system, solar home system, standalone institutional solar PV system, solar PV mini grids, and telecommunication and lighting PV solar systems are being installed [56]. Pico and micro solar systems are mainly adopted by the locals in the villages where there is no natural grid for electricity [57]. The other mini grid PV solar system include: Xsabo solar plant (20 MW) and Mayuge solar PV plant (10 MW).

\subsubsection{Challenges being experienced and their possible mitigation}

The main challenge with solar energy is the environmental impacts. Solar energy does not pollute air, water or cause greenhouse gases. It can have a positive, indirect effect on the environment. Using solar energy replaces or reduces the use of other energy sources that have larger negative effects on the environment. Although, some toxic materials and chemicals are used to make the photovoltaic (PV) cells that convert sunlight into electricity. Some solar thermal systems use potentially hazardous fluids to transfer heat. Leaks of these materials which can harm the environment and cause health effects to human beings and animals. However, environmental effects from solar energy technologies are usually minor which can be minimized by appropriate mitigation measures. The potential environmental burdens of solar energy are regularly site specific, depending on the size and nature of the project. This can be minimized by proper site selection. The selected sites should not interfere with land farming and other land uses. Some of the mitigation strategies concerning community resistance and investments cost can be borrowed from the previous energy system such as hydropower and wind energy $[41,51]$.

\subsubsection{Future trends}

With needs to achieved the $100 \%$ renewable by 2050 , Uganda's will have developed it solar energy four times the existing capacity [33]. This can be simply put as, the need to use solar and other renewable sources of energy will be no more an alternative but a must do thing in a near future. The government of Uganda has therefore started to partnership with the private sector energy providers that can build solar plants in Uganda and learn from them for agreed duration of time.

\subsection{Geothermal Energy}

\subsubsection{Current status of utilization}

Ever since the quest for geothermal potential in this country began, more than 40 geothermal sites have been studied for their prospect's parameters like temperature, chemistry of reservoir, natural heat transfer and fluid characteristics to identify specific project areas and prioritize those for more detailed investigation. So far so good three major potential areas for geothermal energy as detailed in Table 8 [47]. While the latest site discovered is Panyimur geothermal which is located in Pakwach District. 
Table 8. Prospective geothermal sites in Uganda

\begin{tabular}{|c|c|c|c|}
\hline District & Site name & Temperature $\left({ }^{\circ} \mathrm{C}\right)$ & Remarks \\
\hline Kasese & $\begin{array}{l}\text { Katwe- } \\
\text { Kikorongo }\end{array}$ & $\begin{array}{l}\text { Surface } \\
\text { temperature: } 71^{\circ} \mathrm{C} \\
\text { Inferred Reservoir } \\
\text { temperature: } 150- \\
230^{\circ} \mathrm{C}\end{array}$ & $\begin{array}{l}\text { There is sufficient information for development } \\
\text { of geothermal energy programme on Katwe- } \\
\text { Kikorongo site and has been selected for drilling } \\
\text { of a first geothermal well in Uganda. The site } \\
\text { has occurrence of a medium to high } \\
\text { temperature resource. }\end{array}$ \\
\hline Bundibugyo & Bura & $\begin{array}{l}\text { Surface } \\
\text { temperature: } 97^{\circ} \mathrm{C} \\
\text { Inferred Reservoir } \\
\text { temperature: } 120- \\
150^{\circ} \mathrm{C}\end{array}$ & $\begin{array}{l}\text { Nyansimbe and Mumbuga in Buranga } \\
\text { (Sempaya valley) have the highest surface heat } \\
\text { output among the thermal prospects } \\
\text { considered, and provided sufficient information } \\
\text { for development of geothermal energy } \\
\text { programme. }\end{array}$ \\
\hline Hoima & Kibiro & $\begin{array}{l}\text { Surface temp: } 84^{\circ} \mathrm{C} \\
\text { Inferred Reservoir } \\
\text { temp: } 200 \stackrel{\circ}{ } \mathrm{C} \text { and } \\
\text { above }\end{array}$ & $\begin{array}{l}\text { Kibiro site has moderate surface heat output } \\
\text { among the thermal prospects considered, and } \\
\text { provided sufficient information for } \\
\text { development of geothermal energy programme }\end{array}$ \\
\hline
\end{tabular}

Source: Adapted from ERA [47]

\subsubsection{Challenges being experienced and their possible mitigation}

There are 10 challenges which hindered the geothermal development in Uganda: (1) Land access barriers and competition, (2) diversification of Uganda's energy mix, (3) Large investment costs, (4) Lack of awareness and information, (5) Government policy, incentives and institutional challenges, (6) Inadequate research and development, (7) Inadequate human capacity and training, Inadequate infrastructure to support geothermal energy development, (8) Inadequate infrastructure to support geothermal energy development, (9) Shortage of financial resources, (10) Socio-cultural and environmental challenges [58,59].

Several mitigation approaches have been proposed, however, most of the solutions to the challenges are similar with the other energy systems described earlier. Some of the countermeasures for the abovementioned challenges include; Financial and subsidy incentive to individual, communities as well as private organizations for the development of the geothermal energy project and community participation/ownership of geothermal Energy projects for security and infrastructure. Loan facilities can be sought from African Development Bank as well as global environmental facility. Regular environmental audits and environmental systems strengthening and streaming to ensure proper use and restoration of existing ecosystem services [58].

\subsubsection{Future trends}

Until now, all the studied prospects have not yet reached an exploration stage suitable for the targeting and drilling of deep exploration wells. Expected temperatures are suitable for electric power generation using ORC plants, subject to the confirmation of the existence of reservoirs suitable for industrial exploitation. Geothermal energy is one of the possible alternative renewable energy sources in Uganda, which could supplement other sources of energy. Therefore, the country is not giving up on it. The development of technology and skills to extract the geothermal energy from the sites discovered is in progress.

\subsection{Nuclear Energy}

\subsubsection{Current status of utilization}

Uganda's energy scenario is different, nuclear power potential is $24000 \mathrm{MW}$, but preliminary findings indicate 50000 square kilometers of estimated uranium prospects around Buyende, Nakasongola, Mubende, Kiruhura, Buhweju plateau and Lamwo. The unit cost of developing $1 \mathrm{MW}$ of Nuclear energy is U.S \$6 Million. Government efforts are to build a 1000MW power plant in the medium term 
and 2000MW in the long run. Government of Uganda plans to invest in energy infrastructure and raise generation capacity to $3500 \mathrm{MW}$, it also seeks to increase per capita consumption from current $215 \mathrm{kWh}$ to $674 \mathrm{kWh}$ over the medium term [60]. This will be unprecedented energy reform in the country due to it abundance.

\subsubsection{Challenges being experienced and their possible mitigation}

There numerous challenges that are debarring atomic energy development in Uganda besides the danger and the fear of nuclear energy. These challenges include but not limited to the following as highlighted [61]. (i) There is very high initial capital cost of building a 1000MW nuclear power station in Uganda averaged almost U.S $\$ 6$ billion (in 2020 dollars). (ii) There is insufficient public awareness of nuclear power development. Worse still technical information is inadequate, data is insufficient to accurately assess the availability and true potential of nuclear energy. (iii) There is strong competition with other energy sources. (iv) Uganda that has no policy on nuclear energy is not expected to have a waste management policy on nuclear wastes which is quite dangerous for the country. (v) Nuclear technology is very complex and demanding that requires specialized knowledge and excellence in human performance- a rare quality in the country. (vi) Another critical barrier to the development of nuclear energy development in Uganda is the absence of the enabling infrastructure (Grid unreliability) in form of transmission and distribution lines that can transmit Electricity to the remote places and because of this limitation, they resort to rudimentary technologies used in most of the rural places in Uganda are essentially small and very inefficient. (vii) Presently, there is limited research effort by the government of Uganda in nuclear energy. Notably, there is no nuclear energy research and development program that is reinforced with government funding. (viii) One of the most critical challenges is that politics and Geopolitical risks are embedded in nuclear energy development [61-63].

Several countermeasures to the challenges have been pointed out. These includes: The government of Uganda may undertake an energy subsidy reform by transferring subsidies from fossil fuels to nuclear energy technologies. In addition, there is a need for regularizing manufacturing processes in order to promote nuclear energy technology in Uganda. Most of the solution such as capacity building, feed-in-tariffs policies are the similar to other energy systems [64].

\subsubsection{Future trends}

In the face of growing energy needs arising from the rapidly growing population, there is need to find alternative clean, efficient, reliable and affordable sources of energy in Uganda which can meet this need. As such, nuclear energy has been considered a good fit that could cover this unprecedented energy demand as well as soothing socio-economic activities in the country [60].

\subsection{Peat Energy}

\subsubsection{Current status of utilization}

Peat is the surface organic layer of a soil, consisting of partially decomposed organic material, derived mostly from plants, that has accumulated under conditions of waterlogging, oxygen deficiency, acidity and nutrient deficiency. Peatlands are areas of landscape, with or without vegetation, that have a naturally accumulated peat layer at the surface [65]. The peatlands area in Uganda is projected to be about $4000 \mathrm{~km}^{2}$, and the average thickness of peat deposits is estimated to be about $1.5 \mathrm{~m}$ with the total peat volume to be 6000 million cubic metres, while the average dry bulk density is estimated to be around $100 \mathrm{~kg} / \mathrm{m} 3$ and a net calorific value of 17 Giga Joules/tonnes while theoretically, peat volume corresponds to about 250 million tonnes of oil equivalent (Mtoe) [41].

\subsubsection{Challenges being experienced and their possible mitigation}

The damaged peatlands in the country are already releasing almost 3.7 megatons $\mathrm{CO}_{2}$-equivallent each year, which is very dangerous to the environment. Moreover, these emissions are likely to increase with further peatland deterioration as a result of climate change [66]. 
Generally, peatlands need more studies and long-term monitoring in relation to vegetation changes and corresponding ecosystem services such as GHG, water quality, and flooding. This is helpful to support further financial investment. Sharing good practice on peatland management and scientific information across peatland countries is an important objective [66].

\subsubsection{Future trends}

Kabale Energy Limited is the first company entrusted by the ERA to undertake studies necessary for generation of approximately 33MW using peat resource in Kabale District. Meanwhile, ERA is currently processing a permit extension application for the said project. There is hope that the total available peat resource volume would be adequate for generation of about $800 \mathrm{MW}$ for the next 50 years. However, the available peat resources are dispersed mainly to Western and South- Western Uganda, where the desired characteristics are better than in other regions [47].

\subsection{Coal Energy}

\subsubsection{Current status of utilization}

There is currently limited study on the existence, consumption and production of coal in Uganda. This implies that there is no coal deposit and utilization in the country [30].

\subsubsection{Challenges being experienced and their possible mitigation}

Coal production and uses in Uganda has not yet commenced, however, some challenges are attributed from the use of coal as derived from the coal dominant countries such as China and US.

Price inflation is a problem associated with coal in that depletion of the highest-quality, easiestto-mine coal leads to higher prices. The price of delivered coal is also sensitive to oil price increases, because diesel fuel is an important input for mining and transportation. Price inflation can be solved by the value diversity in fuels, technologies, and suppliers in integrated resource planning; this will reduce the tendency of overdependency on coal only by investing in solar, wind, geothermal among others [67].

Environmental constraints and the costs associated with meeting new pollution-control requirements. Environment pollution now has become global concern since the world is eyeing carbon free production and operation therefore new and pending environmental rules are expected to increase substantially the costs of operating existing or building and operating new coal plants, and some of the technologies proposed to better manage emissions [68]. Fully evaluate pollutioncontrol investments for existing power plants and secure option values by evaluating practical options, investigating those that are most promising, and procuring those that produce the most value under the broadest range of plausible future conditions. This will prevent issues associated with environment pollution and global warming due to carbon emission.

There is health issue concerning the use and production of coal. Coal kills people and causes disease from coal-fired power plants causes 23,600 premature deaths, 21,850 hospital admissions, 554,000 asthma attacks, and 38,200 heart attacks every year. Additionally, coal kills jobs compared to other renewable energy sectors like wind and solar. In America wind sector employs more workers than the coal industry. Investing in wind and solar power would create 2.8 times as many jobs as the same investment in coal; mass transit and conservation would create 3.8 times as many jobs as coal [69]. Policy drivers like introduction of stringent environmental regulations which are less favorable against coal have added another dimension to the coal's industry troubles.

\subsubsection{Future trends}

Since there is no much information related to coal deposit in the country. The future trend will only rely on the further exploration with technology that will be available in future. With constant exploration, maybe one day coal deposit can be found in the country. 


\subsection{Petroleum Energy}

\subsubsection{Current status of utilization}

Being a landlocked country, about $85 \%$ of Uganda's petroleum imports are routed through Kenya, and $15 \%$ through Tanzania [9]. However, commercially viable deposits of oil in the around Lake Albert in western Uganda were confirmed in 2006. This will gradually change the petroleum industry in the near futur. Nevertheless, the full exploitation of the deposits might require the construction of an export pipeline to the Indian Ocean coast at Tanzania or Kenya coastal areas, although other possibilities are being examined [70]. The transport sector is the major consumer of fossil fuels and accounts for about $75 \%$ of the fossil-fuel import bill [9]. While the Liquefied Petroleum Gas (LPG) $(0.06 \%)$ and electricity $(0.45 \%)$ make up a relatively small portion of overall household energy demand. Overall, the combined, diesel, and LPG contribute 3.2\% of the sector's energy consumption in the country.

\subsubsection{Challenges being experienced and their possible mitigation}

Several challenges are hindering the development and utilization of petroleum energy. These include but not limited to the following: (i) weak local government capacity, spaces for resource government and industry-driven interaction with the local people [71]. The mitigation strategies of these challenges are similar to one described in the case for the coal energy system.

\subsubsection{Future trends}

Uganda has started it oil extraction at Albertine, the creation of pipeline to Tanzania is proposed by the government. The government also plan to developed its own processing plant. Currently, the country is exporting unprocessed crude oil. Therefore, the future development will be to establish oil refinery plant in the country. Recycling of petroleum products such as polythene, PET bottles, polypropylene into diesel can also be beneficial to the environment as well as increasing fuel supply into the country [72].

\subsection{Non-solid Biomass Energy}

\subsubsection{Current status of utilization}

The non-solid biomass energy includes biofuel, biogas, bioethanol, bio-methanol, biodiesel, and hydrogen. The transition from traditional biomass (wood and charcoal fuel) to modern biomass and biofuel production and consumption is a main focal area of the government meet go green with sustainable energy systems by 2050 [73]. Although there are modern biomass energy systems, using biomass to general electricity present an alternative energy. So far, Kakira Sugar Works Limited and Kinyara Sugar Limited are generating electricity for sale to the national grid from bagasse, providing $12 \mathrm{MW}$ and $5 \mathrm{MW}$ respectively as of the year 2010. Generally, biomass cogeneration from agricultural wastes is seen to hold particular promise as a technology for the country. On the other hand, biogas digester distribution is still very limited in the country. The biogas implementation process started way back in the 1990s, and 50 digesters were installed in five districts (Iganga, Kabarole, Mbale, Mpigi, and Tororo) in the country by 2004 [30, 41]. There are also already power being generated from wood gasifiers at Muzizi Tea Estate $(250 \mathrm{~kW})$ and Mukono gasification system $(10 \mathrm{~kW})$ [74].

\subsubsection{Challenges being experienced and their possible mitigation}

The challenges of development and utilization of non-solid biomass are quite similar with the previous energy systems. Some of the challenges include lack of technology and capacity building, high investment cost, poor country's regulation, policy and standard and so on. Similarly, the mitigation of these challenges can be adopted from the previously discussed energy systems.

\subsubsection{Future trends}


The need for the future development and utilization of non-solid biomass is so demanding as a strategy to address the climate change. The country should expand the existing biogas plants to all villages. Gasification should be studied and adopted in the country. Biofuel or biodiesel, ethanol and methanol production facilities should be developed or expanded since the country is very rich in biomass. There are a lot of underutilized agricultural and agro-processing residues that need to be converted into the useful resource. The future clean energy that is going to change the country energy profile with less or no environmental concern is non-solid biomass [75]. Therefore, the country should plan to forget traditional use of the solid biomass.

\section{Discussions}

Very well, human and animal energy sources are still the utilized energy sources in rural areas of Uganda. However, there is still gap in its utilization. Unfortunately, many youths are currently unemployed and eventually waste resources into activities such as gambling or betting and leisure. In order to harness the harnessed the human and animal to the fullest, there is need to designed proper technology and tools. For instance, mechanization of agriculture is one of the technologies required. By using proper technology and tools, the human and animal energy can be sustainably utilized without making them drudgery.

The traditional cooking stoves that use firwood are still the dominance within the rural population of Uganda. Over dependence on firwood as the source of energy has resulted into deforestation. Nonetheless, it is still a hurdle for the government to provide cheap fuel like firewood to the rural population in order to reduce the over reliance on firewood. Worst still, charcoal a processed wood fuel is being used among the urban people. This makes no difference in term of deforestation, though it is cleaner than firewood with less or no smoke problem. Technology such as briquetting of agricultural residues and municipal wastes (MSW) can be better solution to over utilization of firewood. Use of other energy sources for cooking such as LPG, biogas, electricity, and ethanol is paramount important to minimize over dependence on firwood.

Hydropower is the hope and future for Uganda electricity, as the nuclear, geothermal and wind are still paper work. River Nile is the miracle river for Uganda where most of the large hydropower stations are constructed. The country over dependence on the hydropower for electricity is indeed not very safe for the future. With so many challenges of hydropower such as climate change and high investment and maintenance cost, the country will not meet electricity demand in future. Therefore, the Uganda should continue to explore and develop other energy sources for electricity.

Wind energy in Uganda is still a story with so many questions unanswered whether it will be economically feasible to installed the wind turbines in the sites identified or not. Wind energy require huge amount of land which is not easy to be given out by the local people and compensating all these people will be require enormous capital investment cost. Nevertheless, small wind farm can be established to supply the specific settlement without need to connect to the national grid.

Solar energy from PV cell is currently being adopted by most people in villages. So many places where hydropower national grid is not reaching are massively depending on solar PV electricity to power their electronic devices, lighting, and so many other uses. However, the application of PV electricity should be expanded such as cooking, powering agricultural machines, and crop processing.

Geothermal energy in Uganda has not been development, it is still more of paperwork. There is still much to done to start the harvesting the geothermal energy. The competition with many cheaper energy sources such as hydropower and solar will not make the geothermal energy come to life any time sooner. However, the country should not look down on the geothermal energy because having diverse energy sources is very essential for the sustainability of power utilization in the country.

Nuclear energy, the atomic energy of the future for Uganda. Nuclear is being feared and wanted at the same time. With the availability of large deposit of uranium, Uganda stands at the edge of developing nuclear energy in a nearby future. The only challenge is meeting the 19 nuclear energy infrastructure requirements such as availability of safety regulation, nuclear waste storage, 
technologies, skilled manpower, and so on. Despites the hurdle in overcoming the nuclear energy challenges, the country should never give up. This is because nuclear energy is the only energy that will be reduced the country over dependence on the hydropower for electricity.

Peat energy, the forgotten but very important energy source that can be harnessed cheaply. Uganda is blessed with large peatlands. Peat is not like coal or petroleum; in fact, it is between renewable and fossil fuel. That mean it is not fully fossil fuel or renewable energy source. Utilization of peat will be great opportunity for Uganda to diversify its energy sources which in turn will improve the overall sustainability of the energy sources in the country.

Coal energy, the black gold that is just a story for the country like Uganda. There is no much study done on coal so there is no idea of whether Uganda has coal deposit or not. Importing coal from other country such as Tanzania or DRC will be too expensive for the country to economically benefit from such energy source. Nonetheless, it is better for country to remain without coal utilization. This is because utilization of coal comes with so many problems that the country might not handle.

Petroleum energy is still the only single energy system for transportation industry in Uganda. Petroleum is just full of geopolitics and thus, the main challenge with its utilization. Uganda being the landlock country suffered with importation of petroleum, making the transportation industry unstable in term of fare. The rise in transport cost is the directly linked to the prices of commodities. The newly crude oil mining at Albertine is now the hope for country as much as it is being exported for processing. For country to be self-sufficient in the oil field, it has to developed its own processing plants with all the technologies and human skill required. This is the only way; the country can be independent in its own country.

Lastly, the non-solid biomass such as hydrogen, biofuel, biogas, ethanol, and methanol are very clean and renewable energy sources that country should bet big on them. For instance, biogas can be an alternative to firewood for cooking as well as LPG. Gasification of the agricultural residues and MSW is also potential technology that can be used for cooking and transportation (hydrogen gas). So far so good, the country is trying to develop and install biogas and ethanol plants. However, the country should also look at biomass gasification or even co-gasification with MSW. Co-gasification is vitally important because it is the technology that will be solve both the energy and environmental problem. With these regards, researches are required to understand the suitability of biomass gasification in the country, and also studies are needed to gain insight on the co-gasification process of several feedstock combinations.

\section{Conclusion}

The present study successfully reviewed energy systems in Uganda. Human and energy is the forgotten renewable energy which need to harnessed sustainably to avoid drudgery. Hydropower is still the alpha and omega for the country as far as electric power is concern. There is need for the country to diversify energy system for electricity generation. This far, the only hope for the country future electricity generation is from atomic energy (nuclear energy). Though it is not a renewable energy sources, nuclear energy will be very vital to minimize the country over dependence on the hydropower. Many energy systems are still underdeveloped or underutilized. Geothermal, wind, peat, and nuclear energy systems are still under early stage of development and are not utilized. However, there is a plan for the development to reach the utilization stage in the near future. The present study has not covered in detail, the technologies used for harvesting or harnessing these energy systems. Therefore, further study is required to review the technologies behind the energy systems utilizations, the impact of these technologies on energy development and utilization should be investigated. In additional, several energy systems not covered in this paper including tidal, wave, battery, and gravity storage needs to be investigated for their utilization and development in the country. 


\section{References}

[1] G. Okoboi and J. Mawejje, “Electricity peak demand in Uganda : insights and foresight,” Energy. Sustain. Soc., 2016.

[2] D. Habtu, E. O. Ahlgren, and G. Bekele, "Long-term evolution of energy and electricity demand forecasting : The case of Ethiopia," Energy Strateg. Rev., vol. 36, no. July, p. 100671, 2021.

[3] Joint Research Centre, "Status of Geothermal Industry in East African Countries," 2020.

[4] B. M. Wabukala, J. Otim, G. Mubiinzi, and M. S. Adaramola, “Assessing wind energy development in Uganda: Opportunities and challenges," Wind Eng., vol. 45, no. 6, pp. 1714-1732, Dec. 2021.

[5] ERA, “Electricity Supply Industry Performance Report for the year 2019,” 2020.

[6] S. Kay and S. Kay, "The potentials of technology complementarity to address energy poverty in refugee hosting landscapes in Uganda," Energy, Ecol. Environ., vol. 6, no. 5, pp. 395-407, 2021.

ERA, "Schedule of end-user tariffs applicable for the supply of electricity by umeme limited for the third quarter of the year 2021," Kampala, Uganda, 2021.

[8] M. R. Kakumba, “Despite hydropower surplus, most Ugandans report lack of electricity,” 2021.

[9] R. Tumwesigye, P. Twebaze, N. Makuregye, and E. Muyambi, “Key issues in Uganda's energy sector,” London, 2011.

[10] M. J. Van Der Ven, "An overview of recent developments and the current state of the Ugandan energy sector," E20046-UGA-1, 2020

[11] C. Ang, N. John, C. Oludhe, and I. Chitedze, “Heliyon The role of diversity, reserve margin and system structure on retail electricity tariffs in Kenya," Heliyon, vol. 6, no. March, p. e04626, 2020.

[12] M. Olleik, H. Auer, and R. Nasr, “A petroleum upstream production sharing contract with investments in renewable energy: The case of Lebanon," Energy Policy, vol. 154, no. May 2020, p. 112325, 2021.

[13] H. Ai, S. Xiong, K. Li, and P. Jia, “Electricity price and industrial green productivity : Does the ' low-electricity price trap' exist?," vol. 207, 2020.

[14] W. Athukorala, C. Wilson, S. Managi, and M. Karunarathna, “Household demand for electricity : The role of market distortions and prices in competition policy," Energy Policy, vol. 134, no. February, p. 110932, 2019.

[15] H. Balarama, A. Islam, J. Sung, and L. Choon, “Price elasticities of residential electricity demand : Estimates from household panel data in Bangladesh," Energy Econ., vol. 92, p. 104937, 2020.

[16] C. Deng, Z. Jiang, and C. Sun, “Estimating the Efficiency and Impacts of Petroleum Product Pricing Reforms in China," vol. 2014, no. Figure 1, pp. 1-17, 2018.

[17] H. Güler and C. Tedgren, “Establishing the Optimal Tariff in Rural Electricity Distribution Networks: A case study in Uganda," KTH, 2009.

[18] The Oxford Institute for Energy Studies, “Oil in Uganda : Hard bargaining and complex politics in East Africa," 2015.

[19] ESMAP, "Petroleum Product Markets in Sub-Saharan Africa," 2009.

[20] F. Sexsmith, "Petroleum Markets in Sub-Saharan Africa Petroleum Markets in Sub-Saharan Africa Analysis and," no. March, 2010.

[21] OECD, "The impact of Coronavirus (COVID-19) and the global oil price shock on the fiscal position of oil-exporting developing countries," Paris, 2020.

[22] P. Raghoo and D. Surroop, "Price and income elasticities of oil demand in Mauritius : An empirical analysis using cointegration method," Energy Policy, vol. 140, no. March, p. 111400, 2020.

[23] R. J. Fuller and L. Aye, “Human and animal power - The forgotten renewables," Renew. Energy, vol. 48, pp. 326-332, 2012.

[24] D. Mota-Rojas et al., "The use of draught animals in rural labour," Animals, vol. 11, no. 9, pp. 1-17, 2021.

[25] R. Dennis, "Meeting the challenge of animal-based transport," in A resource book of animal traction network for eastern and southern Africa, Harare, Zimbabwe: Intermediate Technology Publication, 1999, pp. 149-169. 
[26] A. Netam and P. Jaiswal, “Role of animal power in the field of agriculture," Int. J. Avian Wildl. Biol., vol. 3, no. 1, pp. 62-63, 2018.

[27] FAO, “Draught Animal Power: An Overview," Food Agric. Organ. United Nations, pp. 1-12, 2010.

[28] P. Nussbaumer, M. Bazilian, and V. Modi, "Measuring energy poverty: Focusing on what matters," Renew. Sustain. Energy Rev., vol. 16, no. 1, pp. 231-243, 2012.

[29] FAO, "Forests, livelihoods and poverty alleviation : the case of Uganda," Rome, 32, 2013.

[30] K. Mokveld and S. von Eije, “Final Energy Report Uganda," 2018.

[31] F. Mwaura, G. Okoboi, and G. Ahaibwe, “Determinants of household's choice of cooking energy in Uganda," 2014.

[32] G. Bush, S. Nampindo, and C. Aguti, "The Value of Uganda's Forests: A livelihoods and ecosystems approach," Kampala, Uganda, 2003.

[33] M. Gustavsson, O. Broad, M. Hankins, and K. Sosis, “Energy Report for Uganda: A 100\% Renewable Energy Future by 2050," Kampala, Uganda, 2015.

[34] L. C. Culver, “Energy Poverty: What You Measure Matters," Stanford University, CA, 2017.

[35] S. Abolhosseini, A. Heshmati, and J. Altmann, "A Review of Renewable Energy Supply and Energy Efficiency Technologies," Bonn, Germany, 8145, 2014.

[36] P. Breeze, “Hydropower," in Power Generation Technologies, Elsevier, 2019, pp. 173-201.

[37] O. Paish, "Small hydro power: Technology and current status," Renew. Sustain. Energy Rev., vol. 6, no. 6, pp. 537-556, 2002.

[38] C. Kavuma, D. Sandoval, H. Khan, and J. De Dieu, "Analysis of power generating plants and substations for increased Uganda' s electricity grid access," AIMS Energy, vol. 9, no. 1, pp. 178-192, 2021.

[39] ERA, “Performance report of authority for the period of 2010-2015," Kampala Uganda, 2015.

[40] IEA ETSAP, “Hydropower - Technology Brief E06,” 2010.

[41] A. Fashina, M. Mundu, O. Akiyode, L. Abdullah, D. Sanni, and L. Ounyesiga, "The Drivers and Barriers of Renewable Energy Applications and Development in Uganda : A Review," Clean Technol., vol. 1, pp. 9-39, 2018.

[42] H. K. Bahati, A. Ogenrwoth, and J. I. Sempewo, "Quantifying the potential impacts of land-use and climate change on hydropower reliability of Muzizi hydropower plant, Uganda," J. Water Clim. Chang., vol. 12, no. 6, pp. 2526-2554, 2021.

[43] G. Kimbowa and K. A. Mourad, "Assessing the Bujagali Hydropower Project in Uganda," Mod. Approaches Oceanogr. Petrochemical Sci., pp. 162-173, 2019.

[44] P. Jansen and R. Kugonza, “Like fish on land: The impacts of hydroelectric power projects on resettled communities in Uganda and Laos," 2019.

[45] L. Pervin, T. Y. Gan, H. Scheepers, and M. S. Islam, "Application of the hbv model for the future projections of water levels using dynamically downscaled global climate model data," J. Water Clim. Chang., vol. 12, no. 6, pp. 2364-2377, 2021.

[46] P. Pokhrel, K. Ohgushi, and M. Fujita, "Impacts of future climate variability on hydrological processes in the upstream catchment of Kase River basin, Japan," Appl. Water Sci., vol. 9, no. 1, pp. 1-10, 2019.

[47] ERA, “Developments and Investment Opportunities in Renewable Energy Resources in Uganda,” 2013.

[48] Get FiT Uganda, “Annual report 2019," 2019.

[49] BMAU-MFPED, “Water-Pumping Windmills in Karamoja : A wasted Opportunity,” Kampala, Uganda, 2017.

[50] S. Ssenyimba, N. Kiggundu, and N. Banadda, "Designing a solar and wind hybrid system for small-scale irrigation: a case study for Kalangala district in Uganda," Sustain. Soc., vol. 1, pp. 1-18, 2020.

[51] B. M. Wabukala, J. Otim, G. Mubiinzi, and M. S. Adaramola, "Assessing wind energy development in Uganda: Opportunities and challenges," Wind Eng., vol. 45, no. 6, pp. 1714-1732, 2021. 
[52] G. C. van Kooten and G. R. Timilsina, "Wind Power Development: Opportunities and Challenges Resource Economics Department of Economics University of Victoria Wind Power Development: Opportunities and Challenges," 2008-13, 2008.

[53] S. M. Aarakit, V. F. Ssennono, and M. S. Adaramola, "Estimating Market Potential for Solar Photovoltaic Systems in Uganda," Front. Energy Res., vol. 9, pp. 1-10, 2021.

[54] C. Kavuma, D. Sandoval, and H. K. J. de Dieu, "Analysis of solar photo-voltaic for grid integration viability in Uganda," Energy Sci. Eng., pp. 1-13, 2022.

[55] GET FiT Uganda, “Annual Report 2020nda,” Kampala, Uganda, 2020.

[56] R. G. Mugagga, H. Baxter, and N. Chamdimba, “A Comprehensive Review on Status of Solar PV Growth in Uganda A Comprehensive Review on Status of Solar PV Growth in Uganda," J. Energy Res. Rev., vol. 3, no. 4, pp. 1-14, 2020.

[57] O. William, K. Avellino, F. Mwarania, A. A. Wahab, and K. T. Aime, “Uganda Solar Energy Utilization: Current Status and Future Trends," Int. J. Sci. Res. Publ., vol. 8, no. 3, pp. 317-327, 2018.

[58] G. Mutumba and M. S. Adaramola, "Prospects and Challenges of Geothermal Energy in Uganda Prospects and Challenges of Geothermal Energy in Uganda," J. Energy Res. Rev., vol. 9, no. 2, pp. 47-58, 2021.

[59] P. Zakkour and C. Counts, "Formulating a Geothermal Energy Policy, Legal and Regulatory Framework for Uganda," in Proceedings, 6th African Rift Geothermal Conference, 2016.

[60] A. Sah, J. Lovering, O. Maseli, and A. Saxena, "Atoms for Africa: Is There a Future for Civil Nuclear Energy in SubSaharan Africa?," Washington DC, USA, 2018.

[61] C. D. Ferguson, “Nuclear Energy: Balancing Benefits and Risks,” 2007.

[62] IAEA, “Basic infrastructure for a nuclear power project,” Vienna, Austria, 2006.

[63] International Energy Agency and Nuclear Energy Agency, “Technology Roadmap: Nuclear Energy," 2015.

[64] S. E. Uhunamure et al., "Appraisal of nuclear energy as an alternative option in south africa's energy scenario: A multicriteria analysis," Appl. Sci., vol. 11, no. 21, 2021.

[65] World Energy Council, “World energy resources: Peat,” 2013.

[66] H. Joosten, M.-L. Tapio-Biström, and S. Toi, Peatlands - guidance for climate change mitigation through conservation, rehabilitation and sustainable use, 2nd ed. FAO and Wetlands international, 2012.

[67] A. Popa et al., "The Challenges of the U.S. Coal Industry and Lessons for Europe," no. May, pp. 1-72, 2016.

[68] T. Stanton, “Understanding Coal' s Challenges and Recommended Regulatory Responses,” no. 13, 2013.

[69] C. Fuels and G. Warming, "Ten Problems with Coal," no. 2004, pp. 13-14, 2009.

[70] Ministry of Energy and Mineral Development, "The Oil and Gas Sector in Uganda: Frequently asked questions.," 2019.

[71] J. Van Alstine, J. Manyindo, L. Smith, J. Dixon, and I. Amanigaruhanga, "Resource governance dynamics: The challenge of ' new oil' in Uganda," Resour. Policy, vol. 40, pp. 48-58, 2014.

[72] D. K. Omol, O. Acaye, D. F. Okot, and O. Bongomin, "Production of Fuel Oil from Municipal Plastic Wastes Using Thermal and Catalytic Pyrolysis," J. Energy Res. Rev., vol. 4, no. 2, pp. 1-8, 2020.

[73] D. Bamwesigye et al., "Charcoal and wood biomass utilization in uganda: The socioeconomic and environmental dynamics and implications," Sustainability, vol. 12, no. 20, pp. 1-18, 2020.

[74] T. Buchholz, I. Da Silva, and J. Furtado, "Power from wood gasifiers in Uganda: A $250 \mathrm{~kW}$ and $10 \mathrm{~kW}$ case study," in Proceedings of Institution of Civil Engineers, 2012, vol. 165, no. 4, pp. 181-196.

[75] R. Twinomuhangi, A. Martin Kato, and A. M. Sebbit, “The Energy and Climate Change Nexus in Uganda: Policy Challenges and Opportunities for Climate Compatible Development," in Global Warming and Climate Change [Working Title], IntechOpen, 2021, pp. 1-20. 